\title{
Impact of drought on water quality in the Youssef Ben Tachafine dam (Souss-Massa region, Morocco)
}

\author{
FatimaBoudarfa ${ }^{1}$, ElmahjoubGallouli ${ }^{1}$,Mohamed $\mathrm{El} \mathrm{hafa}{ }^{1}$, and HassanOulad Ali $^{1}$ \\ ${ }^{1}$ Biodiversity and Ecosystem Functioning Team, Ibn Zohr University, Faculty of Sciences, \\ Department of Biology, Agadir, Morocco.
}

\begin{abstract}
The Massa catchment area has been experiencing an acute rainfall deficit for several years, which has had direct effects on the filling level of the Youssef Ben Tachafine dam. The objective of this work is to study the impact of the drought on the physicochemical quality and the biological balance of this aquatic ecosystem. A monitoring and bi-monthly analyses of the physicochemical and biological parameters (temperature, dissolved oxygen, $\mathrm{pH}$, conductivity, transparency, manganese, iron, nitrate, ammonium, silica, phosphorus, and chlorophyll- $a$ ) were carried out from January to December 2019. The considerable drop in the level of the reservoir has had a major impact on the degradation of the water quality of the lake and its trophic status. The analysis of the results showed that the trophic state of the Youssef Ben Tachafine dam is between mesotrophic and hypereutrophic.
\end{abstract}

\section{Introduction}

Climate change is now a reality in Morocco, as everywhere else in the world, Morocco is very vulnerable to climate variability. Climate projections established by the National Meteorological Directorate predict an increase in average summer temperatures of around 2 to $6^{\circ} \mathrm{C}$ and a decline of $20 \%$ on average rainfall by the end of the century[1]. This global warming has a direct impact on rainfall, on which the filling rate of dams, groundwater recharge and surface water depend. The hydrological regime of all Moroccan watersheds is characterized by a very high interannual variability marked by the alternation of wet and dry sequences, interspersed with years of high hydraulicity or severe drought[2].

The Youssef Ben Tachafine dam is subject to harsh climatic conditions due to the succession of acute drought cycles. Work carried out on the quality of Moroccan lakes under climatic conditions similar to those of the YBT dam[3, 4], has shown that drought has caused significant changes in the general quality of the aquatic ecosystem.

In this context, we conducted a study during a cycle on the YBT dam, from January to December 2019, which focuses on the analysis of hydrological variations, physico-

\footnotetext{
*Corresponding author: f.boudarfa@gmail.com
} 
chemical and biological parameters. The main goal of this study is to understand the effects of drought on the general quality of the dam and its trophic status.

\section{Materials and methods}

\subsection{General characteristics of the site in study}

From the geographical point of view, the Youssef Ben Tachafine reservoir is part of the 940 $\mathrm{Km}^{2}$ Chtouka plain, which is the natural extension of the Souss plain towards the SouthWest, It is limited to the south by the Oued Massa on which the dam was built, $90 \mathrm{~km}$ south of Agadir, to the north by the Agadir-Biougra road, to the east by the outcrops of the primary formations of the Anti-Atlas and to the west by the Atlantic Ocean (Fig. 1).

From the physiographic point of view, it should be noted that the rugged topography, the wide variety of rocks, the semi-arid climate, the proximity of the desert and the strong winds make this area a large region exposed to erosion and desertification. Demography and agricultural transformations aggravate the situation by depleting natural resources such as natural vegetation and water.

Among the objectives assigned to the Youssef Ben Tachafine dam, is cite the reinforcement of the drinking water supply to the towns of Tiznit and Sidi Ifni as well as to the surrounding centres, in addition the development of irrigation over an area of 19,500 hectares, representing $21.3 \%$ of the total agricultural perimeter of the Souss-Massa.

Water inflows in 2019 to the catchment area of the YBT dam are almost nil, which means that this year can be considered very dry, in comparison to previous years. The reservoir reserve has been reduced by more than $50 \%$ from $78 \mathrm{Mm}^{3}$ in January to less than $39 \mathrm{Mm} 3$ in December 2019, as well as the filling rate (from $26 \%$ to $13 \%$ ), this decrease in level is the result of the average volume regulated for the irrigation of the Chtouka plain $275 \times 10^{3} \mathrm{~m}^{3} /$ month and the evaporated volume ranging from $258 \times 10^{3} \mathrm{~m}^{3}$ recorded in December to $899 \times 10^{3} \mathrm{~m}^{3}$ in June, plus the average volume withdrawn from drinking water, which is $627 \times 10^{3} \mathrm{~m}^{3} /$ month [5]. 


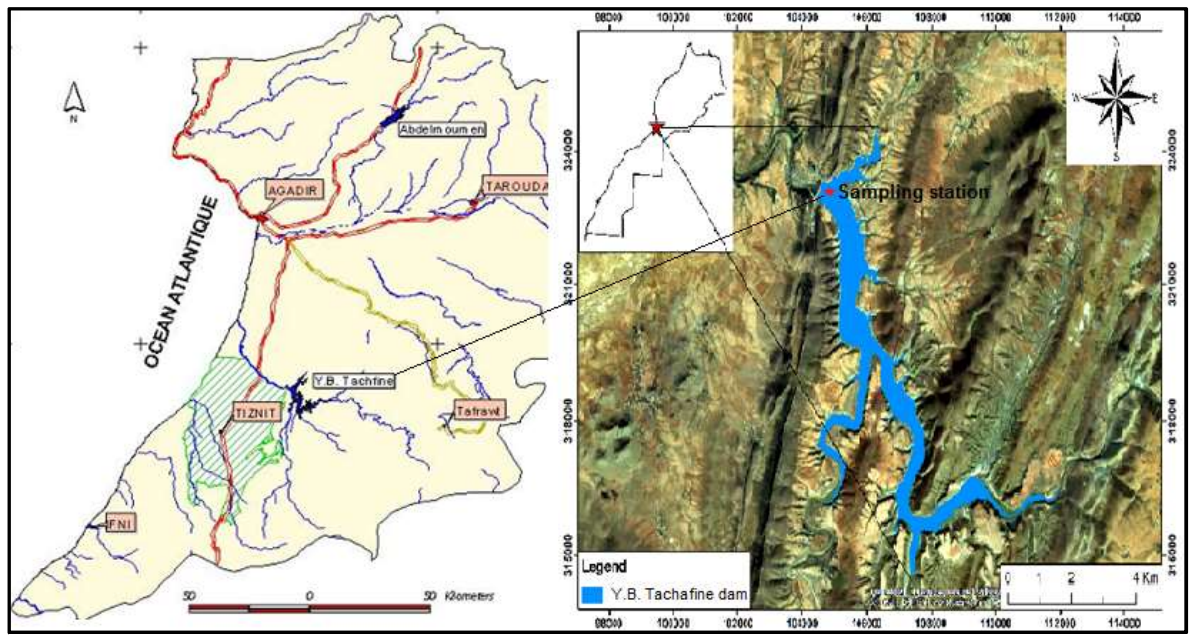

Fig. 1. Schematic representation of the Youssef Ben Tachfine dam.

\subsection{Sampling Points and frequency}

The sampling station (fig1) is located in the deepest part of the dam [5], the water samples were taken at different levels of the column (surface, $2.5 \mathrm{~m}, 5 \mathrm{~m}, 10 \mathrm{~m}, 15 \mathrm{~m}$, and $20 \mathrm{~m}$ ) using a horizontal two-litre WILDKO bottle.These samples were taken between January and December 2019, with a biweekly step and always between 12:00 and 14:00.

\subsection{Parameters measured and methods used}

\subsubsection{In situ measurements}

The temperature, conductivity and dissolved oxygen of the water were measured in situ using a multi-parameter instrument (HI 98196 brand HANNA). Transparency was measured in metres using a Secchi disc immersed in the sampling station, and undesirable substances (iron, manganese and hydrogen sulphide) were determined by the colorimetric method using analytical test kits.

\subsubsection{Analyses carried out in the laboratory}

The water samples were brought to the laboratory and immediately filtered through a 0.45 $\mu \mathrm{m}$ membrane filter. In addition, nutrients (total phosphorus $(\mathrm{Pt})$, ammonium $(\mathrm{NH} 4+)$, and nitrates $\left(\mathrm{NO}_{3}^{-}\right)$) were analyzed using an absorption spectrophotometer according to the water analysis protocol[6, 7].For the determination of chlorophyll "a" the water samples were filtered through Whatman GF/C filters $(0.45 \mu \mathrm{m})$, the pigments were extracted in 30 $\mathrm{ml}$ of hot ethanol and the determination was carried out by measuring the absorbance of the extract with a spectrophotometer at wavelengths $665 \mathrm{~nm}$ and $750 \mathrm{~nm}$ before and after acidification according to the Lorenzen method[8].

Suspended matter is measured by differential weighing of the Whatman $0.45 \mu \mathrm{m}$ filters before and after filtration of the sample and drying in an oven at $105^{\circ} \mathrm{C}$ [7]. 


\subsubsection{Trophic status}

The trophic status was assessed according to the model proposed by the O.C.D.E[9]. This model is based on annual average concentrations of chlorophyll "a", total phosphorus (Pt)and water transparency (Secchi disc).

Table 1summarizes the various parameters measured and methods used

Table 1.Parameters measured and methods used

\begin{tabular}{|c|c|}
\hline Sampling depth in metres & $\begin{array}{l}\text { Surface- } 1-2.5-5-10-15- \\
\text { and the bottom }\end{array}$ \\
\hline Water and plankton sampling & $\begin{array}{l}\text { Horizontal Wildco type bottle of } \\
2 \mathrm{~L} \text { capacity and plankton net of } 20 \mu \mathrm{m} \\
\text { mesh size. }\end{array}$ \\
\hline $\begin{array}{l}\text { Temperature }\left({ }^{\circ} \mathrm{C}\right) \text {, conductivity } \\
(\mu \mathrm{s} / \mathrm{cm}), \mathrm{pH} \\
\text { and } \mathrm{O}_{2} \text {-dissolved }(\mathrm{mg} / \mathrm{l})\end{array}$ & $\begin{array}{l}\text { Multiparameter apparatus } \\
\text { (Hanna brand) }\end{array}$ \\
\hline Transparency in meters & Secchi disk \\
\hline Suspended solids (TSS) in mg/l & $\begin{array}{l}\text { Filtration on a } 0.45 \mu \mathrm{m} \text { filter } \\
\text { then weighed after passing through the } \\
\text { oven and the desiccators. }\end{array}$ \\
\hline $\begin{array}{l}\text { Iron, manganese and hydrogen } \\
\text { sulphide in } \mathrm{mg} / \mathrm{l}\end{array}$ & Colorimetry (Analysis Kits) \\
\hline $\mathrm{NO}_{3}^{-}, \mathrm{NH}_{4}^{+}, \mathrm{Pt}$, and $\mathrm{Si}$ in $\mathrm{mg} / \mathrm{l}$ & Spectrophotometry \\
\hline $\mathrm{Chl}$ "a" in $\mu \mathrm{g} / \mathrm{l}$ & Ethanol extraction \\
\hline
\end{tabular}

\section{Results}

\subsection{Temperature}

Large variations in the dam water temperatures are recorded from one season to the next. During the winter period, the water column is slightly homothermal. The temperature begins to rise at the end of March $\left(19.13 \mathrm{C}^{\circ}\right)$ to reach its maximum in August $\left(27.32 \mathrm{C}^{\circ}\right)$. A direct stratification settles by creating a thermocline $10 \mathrm{~m}$ deep from early June. This thermal cycle classifies the waters of the Youssef Ben Tachafine dam in the category of warm monomictic lakes (Fig.2). 


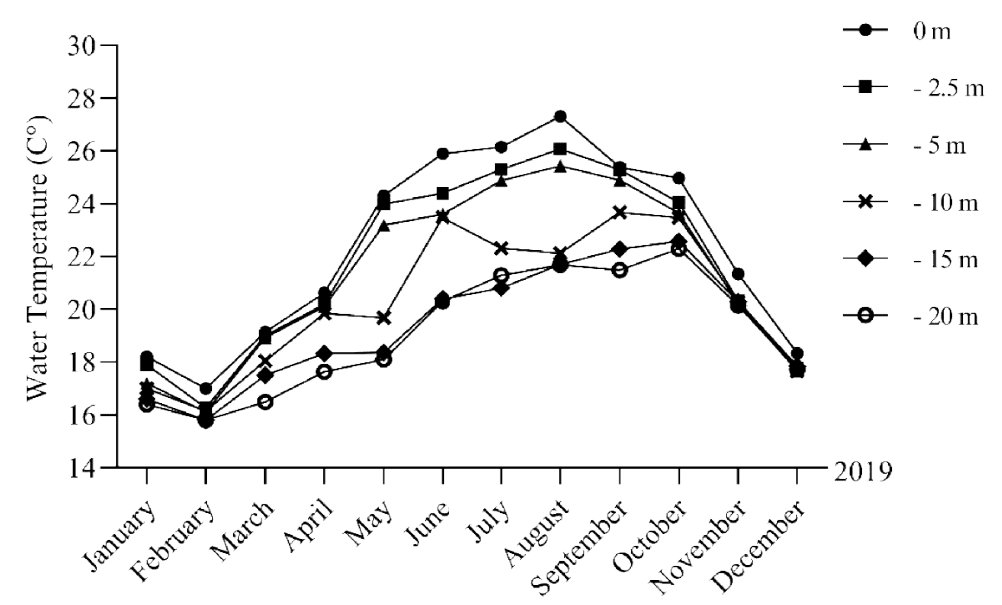

Fig.2. Spatial and temporal changes in water temperature in Youssef Ben Tachafine dam.

\subsection{Hydrogen potential $(\mathrm{pH})$}

The $\mathrm{pH}$ of the water in the YBT dam remains generally alkaline, fluctuating between 7.51 and 9.13, with the highest values being recorded during spring and summer, particularly in the surface layers, reflecting the intensity of photosynthetic activity in the euphotic layers of the lake. However, a slight acidity of the deep water was observed from April onwards, in parallel with the installation of the thermal stratification (Fig. 3).

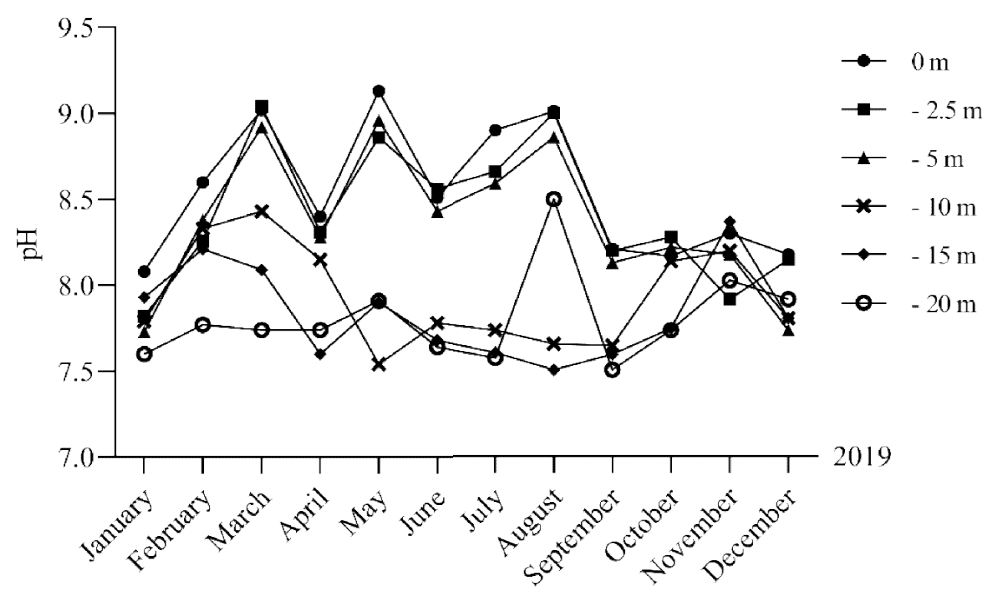

Fig. 3. Spatial and temporal changes in water $\mathrm{pH}$ in Youssef Ben Tachafine dam.

\subsection{Conductivity}

The degree of mineralization is identical over the entire water column, the maximum is recorded in December $(600 \mu \mathrm{s} / \mathrm{cm})$. The seasonal evolution of the conductivity of the water in the YBT reservoir is well marked over time. This being justified by the drop in the water level in the lake, which leads to a concentration of ionisable elements in the water (Fig. 4). 


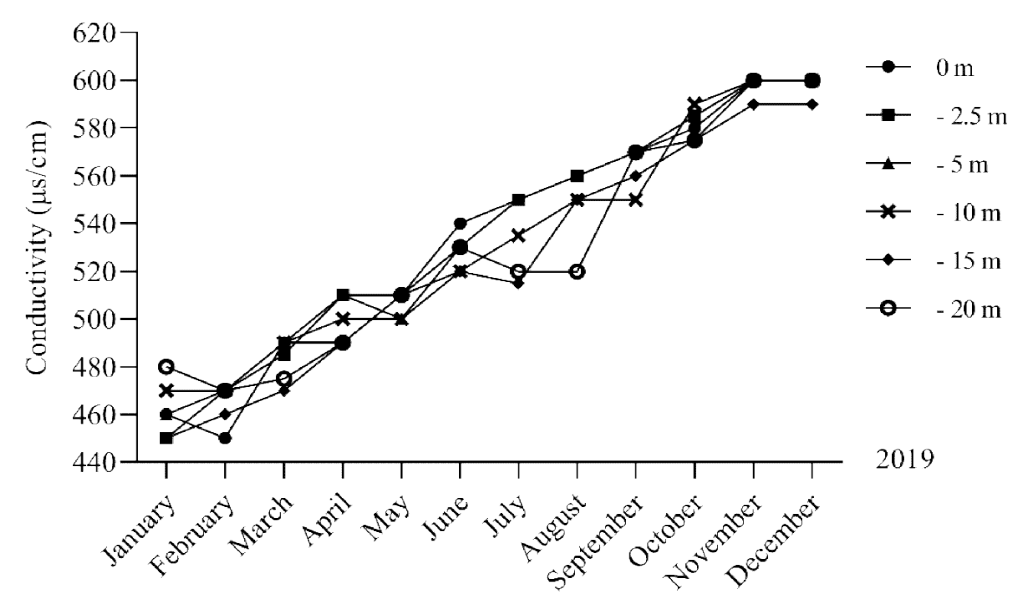

Fig. 4. Temporal changes in conductivity in Youssef Ben Tachafine dam.

\subsection{Dissolved oxygen}

The water in the reservoir is relatively oxygenated in the surface layers, however the deep layers quickly lose their oxygen reserves and tend towards total anoxia, in parallel with the beginning of the installation of thermal stratification which takes place from early spring to autumn (Fig. 5). The drought conditions led to a marked oxygen deficit. Due to the reduction in the height of the water column, the resuspension of organic matter and detritus promotes biodegradation throughout the water column.

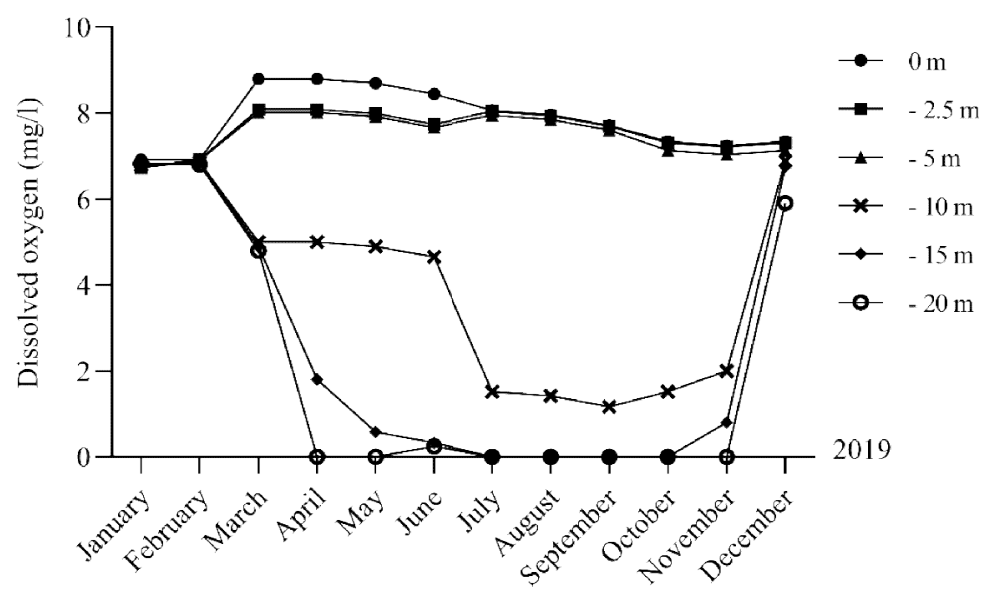

Fig. 5. Spatial and temporal changes in dissolved oxygen content in Youssef Ben Tachafine dam.

\subsection{Manganese, iron and hydrogen sulphide}

Deep water anoxia generates the formation of hydrogen sulphide and other undesirable chemicals such as $\mathrm{Mn}^{2+}$ and $\mathrm{Fe}^{2+}$. High values are recorded in summer and autumn at the bottomof the reservoir $\left(\mathrm{Mn}^{2+}=0.9 \mathrm{mg} / \mathrm{l}, \mathrm{Fe}^{2+}=0.6 \mathrm{mg} / \mathrm{l}\right.$ and $\left.\mathrm{H}_{2} \mathrm{~S}=0.25 \mathrm{mg} / \mathrm{l}\right)$ due to the release of sediment under anaerobic conditions (Fig. 6). 


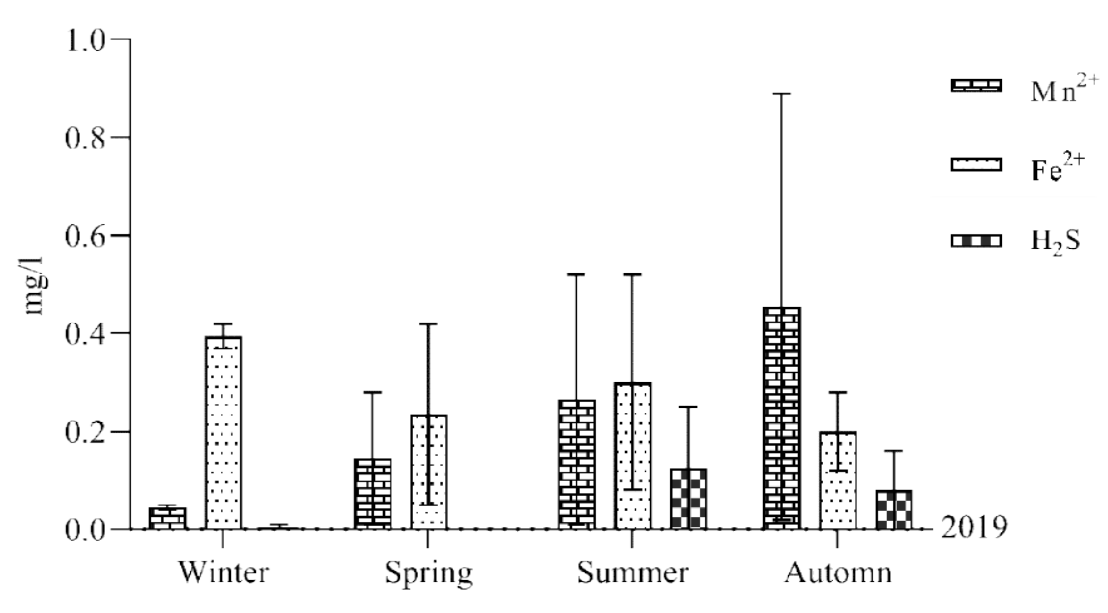

Fig. 6. Seasonal variation of manganese, iron and hydrogen sulphide at Youssef Ben Tachafine dam.

\subsection{Chlorophyll "a", TSS and water transparency}

The phytoplankton biomass represented by chlorophyll "a" levels during the study period shows two peaks, the first in early spring $(9.9 \mu \mathrm{g} / \mathrm{l})$ and the second in early fall $(10.5 \mu \mathrm{g} / \mathrm{l})$.

The water transparency varies between a minimum of $0.30 \mathrm{~m}$ recorded at the beginning of January and a maximum of $1.6 \mathrm{~m}$ at the beginning of May, with an average transparency of about $1 \mathrm{~m}$. These low depths of secchi disc disappearance can be explained by the increase in algal biomass in the euphotic zone in spring and fall (Fig. 7) and by the increase in suspended matter during the water mixing period (Fig. 8).

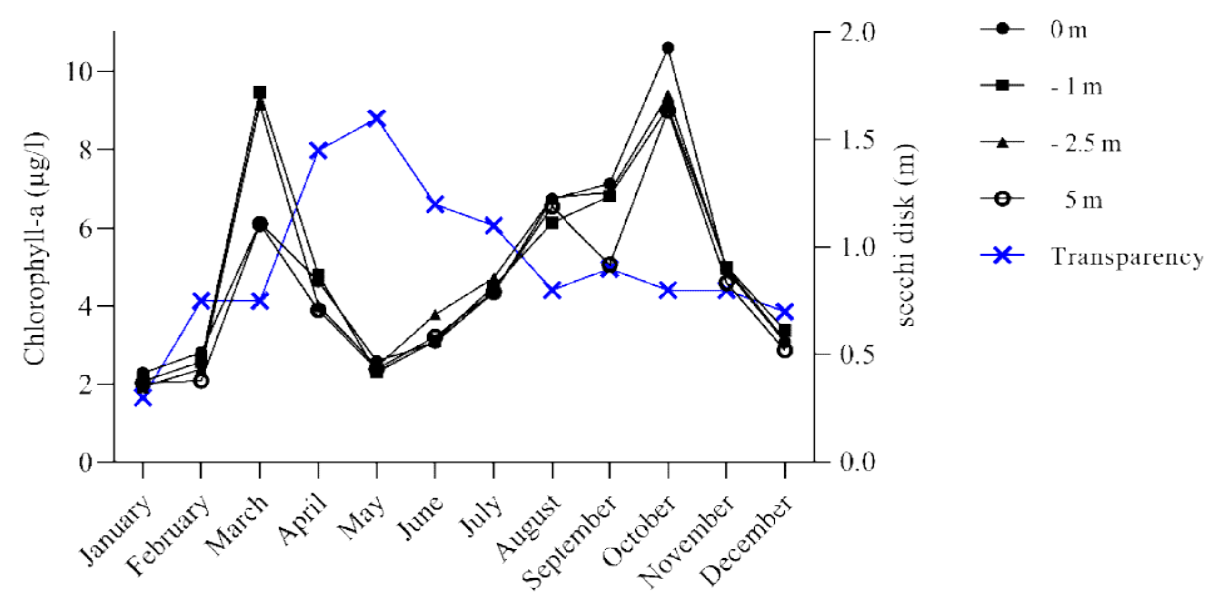

Fig. 7. Temporal changes in the chlorophyll a and the secchi disc depth in Y.B. Tachafine dam. 


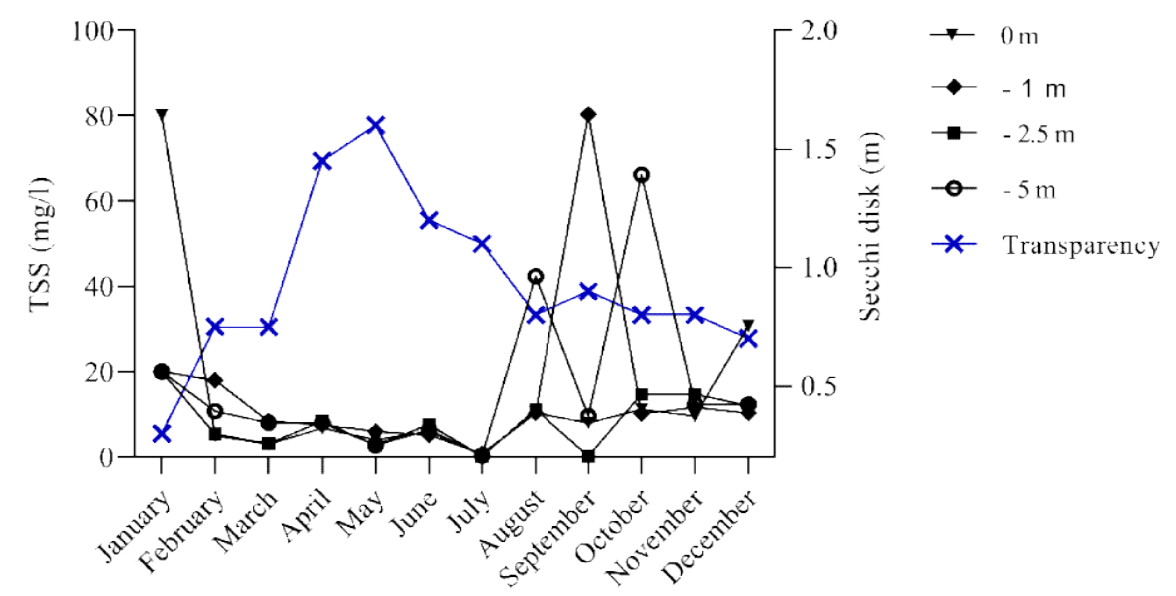

Fig. 8. Temporal changes in total suspended solids and the secchi disc depth in Y. B. Tachafine dam.

\subsection{Nutriments}

\subsubsection{Nitrate and Ammonium}

Nitrate levels recorded in the water column of the Youssef Ben Tachafine dam are high in winter $(2.82 \mathrm{mg} / \mathrm{l})$, while concentrations decrease to zero in summer in the surface layers (Fig. 9). These anoxic conditions at the bottom of the dam facilitate the reduction of nitrates by denitrification [10]

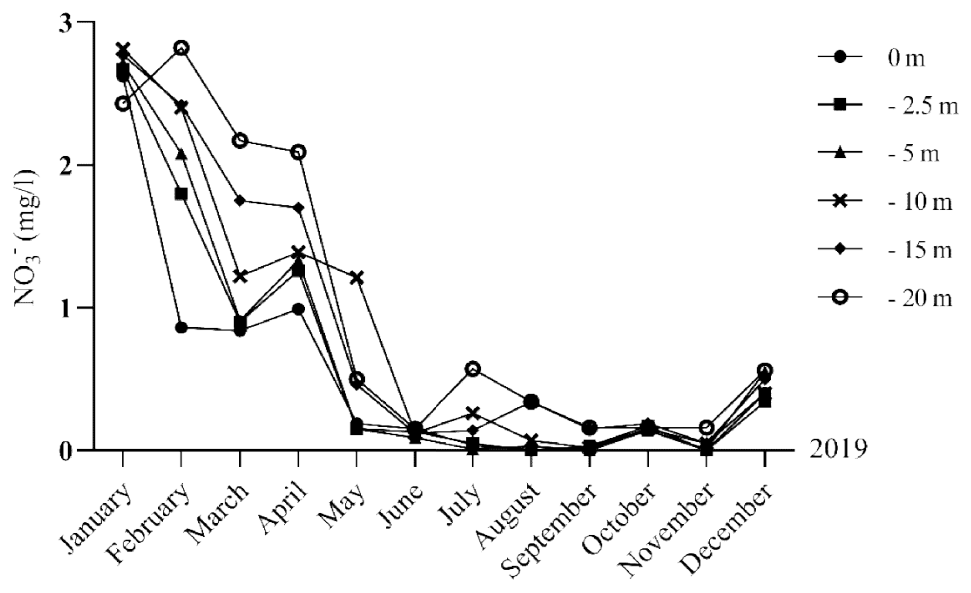

Fig. 9. Temporal changes of nitrates at Youssef Ben Tachafine dam.

Ammonium values vary according to the seasons, the highest concentrations are recorded in hypolimnium in summer $([\mathrm{NH} 4+]=1.58 \mathrm{mg} / \mathrm{l})$ and autumn $([\mathrm{NH} 4+]=1.46 \mathrm{mg} / \mathrm{l})$ (Fig. 10). This is probably the result of the degradation of nitrogenous organic matter. 


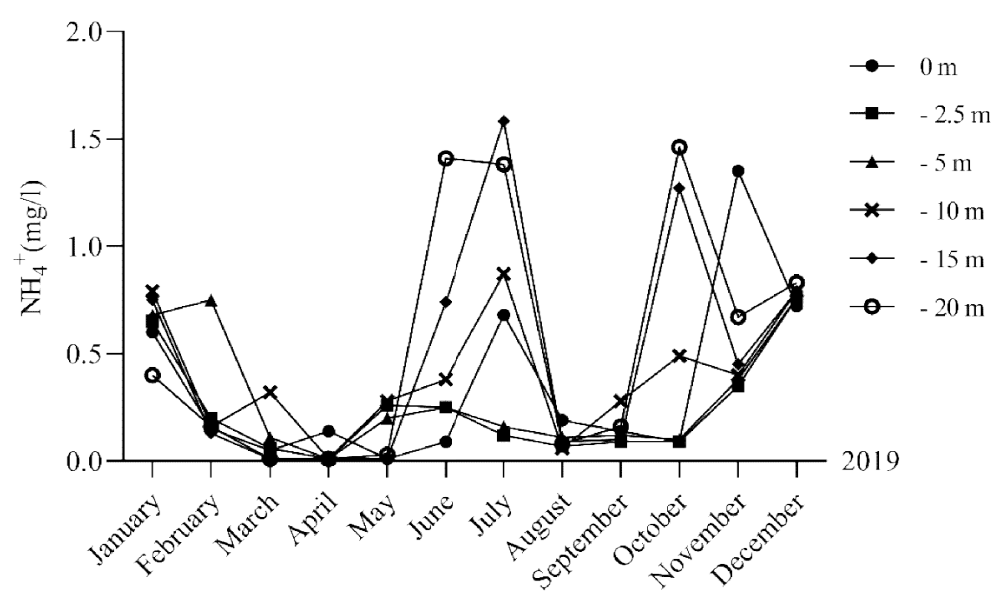

Fig. 10. Temporal changes of ammonium at Youssef Ben Tachafine dam.

\subsubsection{Total Phosphorus}

Total phosphorus levels show significant fluctuations in the water column, ranging from $0.00 \mathrm{mg} / \mathrm{l}$ in summer to $0.34 \mathrm{mg} / \mathrm{l}$ in winter, with a slight increase noted in autumn. From April onwards, total phosphorus levels are distributed along an increasing gradient from the surface to the bottom of the lake. This is due to the release of phosphorus from anoxic sediments during summer stratification. [11], this phenomenon has already been observed in other Moroccan reservoirs, such as El Kansera, Al Massira, and Mansour Eddahbi,[3, 4, 12](Fig. 11)

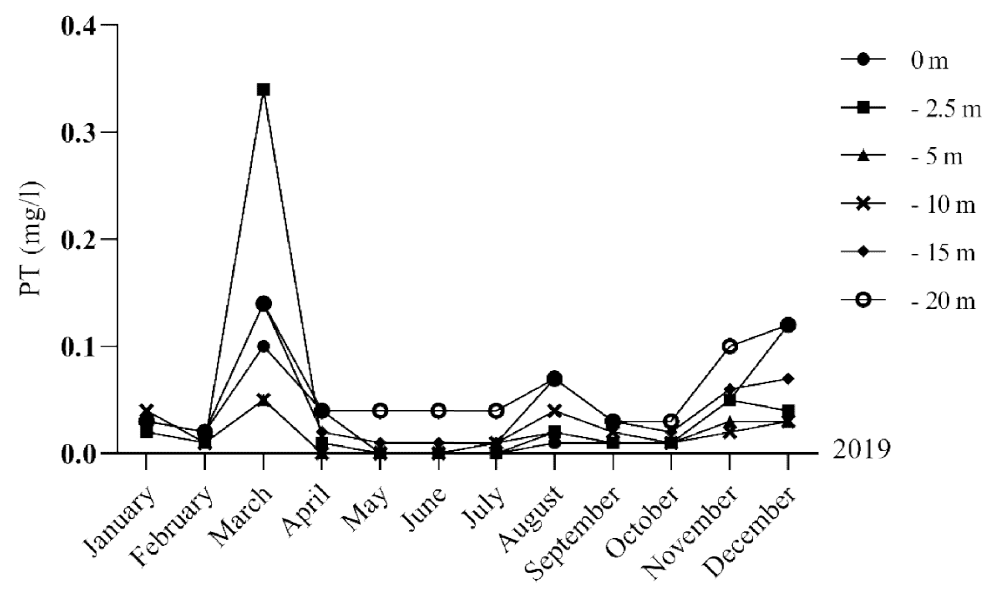

Fig. 11. Temporal changes in total phosphorus in Youssef Ben Tachafine dam.

\section{Discussion}

The hot and dry climatic conditions of the Massa catchment area have led to a considerable reduction in the volume of water and a significant drop in the filling rate of the YBT dam, leading to a concentration of ionisable elements and consequently a strong mineralisation of 
the water in this dam. Indeed, the installation of the thermocline between $10 \mathrm{~m}$ and $12 \mathrm{~m}$ depth during the stratification period reduced the volume ratio of anoxic layers compared to oxygenated layers by intensifying the exchanges between the sediments and the water column.

Under these conditions of total and early deep water anoxia, sediment plays an important role in water quality[13, 14]. The acceleration of the eutrophication phenomenon causes the degradation of the organoleptic quality of the waters of this reservoir by the appearance of hydrogen sulphide, manganese and iron with all their negative consequences on the various uses of the water including in particular the production of drinking water[1517]. Concerning nutrients, there is a high loss of nitrogenand high denitrification during the stratification period. The anoxic conditions at the bottom of the lake facilitate the reduction of nitrates[18] and the increase of ammonium by denitrification [10].The same phenomenon has been underlined by several authors at the levels of other Moroccan dams[19-21]. These ammonium values are higher than those found during a study carried out on the same site more than twenty years ago [22]. Nitrates are rapidly consumed at the surface and decrease throughout the water column, while ammonium ions and total phosphorus are consumed at the surface and released by sediments on the lake bottom. The depletion of phosphorus and nitrates in the surface layers will probably be the limiting factors for phytoplankton production in the Youssef Ben Tachafine dam. The recorded algal biomass is maintained during the study period, despite the absence of external inputs, appears to be the result of internal enrichment of the lake with nutrients from sediment release during the period of thermal stratification and deep-sea anoxia.

In addition, the algal biomass and the re-suspension of the sediments lead to a significant reduction in the transparency of the water in the reservoir. The transparency parameter appears to be a good descriptor of water quality and representative of the trophic level of this reservoir.

Comparing our results with those of Ait Salah[22], especially nitrogen and phosphorus, the two main indicators of eutrophication, it can be seen that the YBT impoundment has evolved towards a eutrophic state. According to the trophic classification proposed by the O.C.D.E. model [9], The trophic status of the YBT reservoir lies between mesotrophy and hyper-eutrophy.

\section{Conclusion}

In the light of these results, we can conclude that the drought conditions caused by global warming and hydrological changes over the last two decades have had a negative impact on the water quality of the YBT dam reservoir and its trophic status. One of the first consequences is the early installation of thermal stratification and total anoxia of the deep layers with the presence of manganese throughout the study period. In addition, the reduction in the volume of water in the reservoir and the high water temperature favoured the strong mineralisation of the water and the enrichment of the water column with nutrients from sedimentation and decomposition, with all their negative consequences on the functioning of this precious ecosystem. The evolution of the trophic status of this reservoir from mesotrophy to hyperotrophy is the direct consequence of all these changes. 


\section{References}

1. I. Motib, M. Batchi, F. Fatah, Conservation Des Ressources Naturelles Pour Une Sécurité Alimentaire Durable Au Maroc, ESJ16, 240 (2020)

2. E. Ouharba, Z. Triqui, R. Moussadek, Impact of Climate change on the Bouregreg Watershed Vegetation and Forest of Morocco, IJASRE5, (2019)

3. M. Sadani, N. Ouazzani, L. Mandi, J Water Sci 17, (2004)

4. D.F. Berrada, R. Berrada, A. Benzekri, ANN LIMNOL-INT J LIM, EDP Sciences, 155-166 (1999)

5. A.B.H.S.M, Agence de bassin hydraulique du Sous Massa, (Maroc, 2019)

6. Afnor, In recueil des normes françaises des eaux, méthodes d'essais, 622 (1994)

7. J. Rodier, Water analysis: Natural water, seawater.Dunod Paris Edition, (1994)

8. C.J. Lorenzen, Determination of chlorophyll and pheo-pigments: spectrophotometric equations, Limnol Oceanogr12,343-346 (1967)

9. O.C.D.E, Eutrophisation des eaux: méthodes de surveillance, d'évaluation et de lutte, Paris, 165 (1982)

10. P. Bonin, M. Gilewicz, J. Bertrand, Effects of oxygen on each step of denitrification on Pseudomonas nautica, Can J Microbiol35, 1061-1064 (1989)

11. A. Rapin, M. Rabiet, M. Grybos, B. Mourier, A. Fay, T. Kestens, V. Deluchat, Distribution spatiale et mobilité du phosphore sédimentaire dans une retenue hydroélectrique, J Water Sci 30, 71-76 (2017)

12. S. Kemmou, J.-E. Dafir, M. Wartiti, M. Taoufik, Variations saisonnières et mobilité potentielle du phosphore sédimentaire de la retenue de barrage Al Massira (Maroc), WATER QUAL RES J41, 427-436 (2006)

13. E. Gautreau, L. Volatier, G. Nogaro, E. Gouze, F. Mermillod-Blondin, The influence of bioturbation and water column oxygenation on nutrient recycling in reservoir sediments, Hydrobiologia 847,1027-1040(2020)

14. A.N. Cojean, M.F. Lehmann, E.K. Robertson, B. Thamdrup, J. Zopfi, Controls of H2S, $\mathrm{Fe} 2+$, and $\mathrm{Mn} 2+$ on Microbial NO3--Reducing Processes in Sediments of an Eutrophic Lake, FRONT MICROBIOL11, 1158 (2020)

15. D. Zogo, H. Soclo, M. Bawa, M. Gbaguidi, Distribution des résidus de fer et de manganèse le long de la colonne d'une retenue d'eau en cours d'eutrophisation: Cas du barrage de l'Okpara à Parakou au Benin (Journée d'Étude du CEBEDEAU, Tribune de l'Eau, 2008)

16. H. Erraji, Les contraintes climatiques et hydrologiques sur le comportement du Fer et du Manganèse dans la retenue du barrage Smir au Maroc, (2016)

17. A. Foutlane, A. Bouloud, K. Ghedda, Restauration de la qualité des eaux des retenues de barrages, IAHS Publications-Series of Proceedings and Reports-Intern Assoc Hydrological Sciences243, 287-298 (1997)

18. Y. Chen, C. Peng, J. Wang, L. Ye, L. Zhang, Y. Peng, Effect of nitrate recycling ratio on simultaneous biological nutrient removal in a novel anaerobic/anoxic/oxic (A2/O), BAF system, BioresourTechnol102,5722-5727(2011)

19. S. Niazi, M. Snoussi, A. Foutlane, Impact of climatic variability on water quality in a semiarid hydrosystem: the Nekkor catchment area (Morocco), SECHERESSE16, 183187 (2005) 
20. M. Loudiki, Etude limnologique d'un hydrosystème récemment aménagé dans la région de Marrakech (Maroc): apports du bassin versant, hydrochimie, algues et macrophytes (Thèse, Aix-Marseille Université, 1990)

21. H.A. Hammou, D. Latour, S. Samoudi, K. Mouhri, M. Douma, J. Robin, M. Loudiki, Occurrence of the First Toxic Microcystis Bloom in a Recent Moroccan Reservoir, Water Resour45, 409-417 (2018)

22. H. Ait Salah, Organisation et structure des communautés zooplanctoniques de la retenue Youssef Ben Tachfine (sud de Maroc) (Thèse, Univ.Ibn Zohr, Faculté des science Agadir, 1997) 